\title{
СТРУКТУРА ТА ЗМІСТ ПРАВОВІДНОСИН, ЩО ВИНИКАЮТЬ У СФЕРІ ЗАСТОСУВАННЯ ДОПОМІЖНИХ РЕПРОДУКТИВНИХ ТЕХНОЛОГІЙ
}

\author{
ДАВИДЮК Христина Валеріївна - аспірант кафедри міжнародного \\ приватного права, Інституту міжнародних відносин Київського національного \\ університету ім. Т. Шевченко
}

ORCID ID 0000-0003-2726-3604

DOI 10.32782/LAW.UA.2021.2.22

Метою написання зазначеної наукової роботи є визначення, аналіз $i$ узагальнення структури та змісту правовідносин, щзо виникають у сфері застосування допоміжних репродуктивних технологій.

Модель: методологія проведеного наукового дослідження включила в себе наступні методи: порівняльний метод, метод систематизаиї та соціальне опитування співробітників медичних організачій, які надають послуги із використання допоміжних репродуктивних технологій, аналіз судової практики.

Висновки: у результаті дослідження автор зазначає, що правовідносини у сбері використання допоміжних репродуктивних технологій виникають на момент укладення договору про використання допоміжних репродуктивних технологій з метою лікування безпліддя потениійних батьків за допомогою народження в їх інтересах дитини сурогатною матір'ю для встановлення дитячобатьківських відносин як сімейної иінності потениійних батьків.

Межі дослідження: дослідження проводилося з використанням національного та зарубіжного досвіду нормативно - правового регулювання суспільних правовідносин із дослідженням судової практики України та держав-членів Ради Европи.

Практичне значення дослідження: результати проведеного наукового дослідження можуть бути використані як при підготовці галузевого законодавства, так $і$ при підготовиі проєктів договорів про застосування допоміжних репродуктивних технологій.
Сочіальні наслідки дослідження: розробка спеціального законодавства у галузі репродуктивних технологій забезпечить реалізацію принципу правової визначеності в суспільстві, зменшить конблікти між людьми, які беруть участь у иих відносинах, $i$ може призвести до збільшення кількості дітей, народжених в Україні.

Оригінальність: у роботі акцентовано на важливості законодавчого закріплення структури та змісту правовідносин, що виникають у сбері застосування допоміжних репродуктивних технологій, визначено коло питань, які можуть бути врегульовані законодавцем, а до їх законодавчого закріплення - можуть бути визначеними $і$ вирішитися учасниками правовідносин у договорі.

Ключові слова: правове регулювання, правовідносини, принципи, допоміжні репродуктивні технології (ДРТ), медичні технологій, екстракорпоральне запліднення (ЕКЗ), ембріон людини, біоетика.

Постановка проблеми у загальному вигляді та їі зв'язок із важливими науковими чи практичними завданнями

Людина, її здоров'я та життя, честь і гідність, недоторканність і безпека визнані найвищими соціальними цінностями в Україні. Гарантії забезпечення прав і свобод людини визначають зміст і спрямованість діяльності органів державної влади. Встановлення та захист прав і свобод людини є головною відповідальністю держави. Одним із базових 


\section{Цивільне, підприємницьке, господарське та трудове право}

природних прав є право людини на продовження роду.

Відповідно до ст. 51 Конституції України сім'я, материнство і батьківство, дитинство охороняються державою. Однак значна частина людей не має можливості реалізувати своє право стати батьками за станом здоров'я, а саме через безпліддя. Проблема безпліддя у сім'ї розповсюджена у всьому світі, тому для їі вирішення представниками медичної науки були розроблені сучасні методики лікування - допоміжні репродуктивні технології (ДРТ). Використання допоміжних репродуктивних технологій дає можливість людині реалізувати свої репродуктивні можливості. На сучасному етапі відбувається активний розвиток наукових технологій, що зумовлюе появу унікальних суспільних відносин, які вимагають особливого правового регулювання.

Відсутність закону про ДРТ, у першу чергу, породжує питання про умови застосування методів допоміжної репродукції ^юдини, а також про правовий статус усіх суб'єктів правовідносин, що виникають при використанні ДРТ (пацієнтів, сурогатних матерів, донорів репродуктивних тканин, реципієнтів).

3 впровадженням у практику методу донорства статевих клітин і ембріонів актуальності набуває питання про допустимість оплатного донорства репродуктивних тканин. Не меншу актуальність має проблема визначення правового положення ембріона людини і розробка механізму його правової охорони. У силу того що ембріон не є суб'єктом правовідносин, його життя як життя тільки «майбутньої людини» не охороняється ні Конституцією України, ні сімейним законодавством. У той же час зарахувати ембріон до об'єктів цивільних прав і захистити його за допомогою норм цивільного законодавства також неможливо.

Таким чином, існують значні прогалини у сфері правового регулювання застосування ДРТ. Багато із зазначених вище питань сьогодні є предметом наукових дискусій, i всі вони вимагають якнайшвидшого вирішення.
Аналіз останніх досліджень i публікацій, у яких започатковано розв'язання цієї проблеми і на які спирається автор, виділення не вирішених раніше частин загальної проблеми, котрим присвячується означена стаття

Правовому регулюванню відносин, що виникають при використанні ДРТ, присвятили праці багато вчених. Так, аналіз правових умов, необхідних для застосування цих медичних технологій, проведено в роботах А.П. Головащука, Н. А. Абіляптової, К. М. Світнева, Н. С. Байборошу, О. Розгон, I. В. Венедіктової, Д. Журавльова. Проте, до цього часу багато проблем теоретичного и практичного характеру, що охоплюються предметом цього дослідження, потребують детального вивчення.

Проблемі визначення юридичного статусу ембріона людини приділено значну увагу в монографічних і дисертаційних дослідженнях Е. А. Панкратової, Е. В. Перевозчикова, Г. Б. Романовського, О. С. Нікітіної, С. С. Шевчук, О. Е., Старовойтової. Морально-етичні питання ДРТ розглянуті в роботах I. В. Силуянова, А. Ф. Курило, А. Н. Нікітіна.

Однак об'єктом дослідження зазначених учених, як правило, є не весь комплекс проблем, пов'язаних із застосуванням ДРТ, а лише окремі його аспекти. Причому, значна частина досліджень, присвячених ДРТ, уже втратила свою актуальність, оскільки багато нормативних актів, на які спиралися автори при написанні робіт, сьогодні або втратили силу, або зазнали значних змін.

Таким чином, можна констатувати, що в науці цивільного та сімейного права в цей час не існує єдиного погляду на більшість питань, що мають відношення до правового регулювання правовідносин, що виникають у сфері застосування допоміжних репродуктивних технологій.

\section{Формулювання цілей статті (постановка завдання)}

Метою написання зазначеної наукової роботи є визначення, аналіз і узагальнення структури та змісту правовідносин, що виникають у сфері застосування допоміжних репродуктивних технологій. 


\section{Виклад основного матеріалу дослідження з повним обгрунтуванням отриманих наукових резудьтатів}

У житті людини формуються різноманітні соціальні зв'язки, що пов'язано з ії вступом у значну кількість суспільних правовідносин. Ці правовідносини регулюються нормами права, проте із розвитком наукових технологій формуються нові правовідносини, які раніше не були регламентовані правовими нормами. До них належать правовідносини, що виникають при використанні допоміжних репродуктивних технологій (далі -ДРТ). Чинне законодавство України визначає ДРТ як методику лікування безпліддя, при якій маніпуляції з репродуктивними клітинами, деякі етапи підготовки репродуктивних клітин, процес запліднення ембріонів і їх розвитку до перенесення їх у матку пацієнтки реалізується в умовах in vitro [1].

Зазначені правовідносини мають елементи сімейних та цивільних правовідносин, тому за своїм характером належать до комплексних правовідносин. За своїм змістом відносини щодо застосування допоміжних репродуктивних технологій - це відносини 3 надання медичних послуг, які спрямовані на покращення репродуктивного здоров'я людини з метою реалізації її репродуктивних прав. [2; с.363] При цьому, на думкуM. Ловрі (Greil AL, Slauson-Blevins KS, Lowry M, et al. (2019)) сімейні правовідносини можуть виникнути лише після появи дитини на світ, а до моменту народження правовідносини регулюються укладеним цивільним договором та нормами цивільного законодавства [3; с.16].

Правовідносини у сфері використання ДРТ за своїм функціональним призначенням належать до регулятивних, адже вони регулюють правовідносини між суб'єктами; мають вольовий характер, і тому можуть виникнути і реалізовуватися тільки за умови волевиявлення учасників зазначених правовідносин, тобто волевиявлення учасників 6 необхідним для винекнення досліджуваних відносин. Правовідносини у сфері використання ДРТ за формою здійснення права є зобов' язальними, а за змістом поведінки сторін - активні.
Як правило, між учасниками правовідносин з використання допоміжних репродуктивних технологій укладається договір, що є підставою виникнення правовідносин, а отже, вони належать до договірних правовідносин.

При застосуванні допоміжних репродуктивних технологій як медичних послуг в якості об'єкта впливу виступає здоров'я. Дії, що вчиняються при наданні зазначених медичних послуг, забезпечують збереження, поліпшення або відновлення здоров'я.

На думку Ф. Дель Pio (Piersanti, V., Consalvo, F., Signore, F., Del Rio, A., \& Zaami, S. (2021)), юридичним об'єктом зазначених правовідносин є дії, результат яких не має матеріального вияву [4]. Що ж стосується матеріального об'єкта правовідносин з допоміжних репродуктивних технологій, то він відсутній.

Зміст правовідносин у сфері використання ДРТ становлять суб'єктивні права та обов'язки учасників зазначених правовідносин, регламентовані законодавством та встановлені у договорі.

У досліджуваних правовідносинах варто виділити договірні правовідносини та особисті немайнові правовідносини. Особисті немайнові правовідносини у сфері використання ДРТ можуть виникати на основі норм цивільного права; регламентовані нормами цивільного законодавства і полягають у захисті репродуктивних прав особи.

Об'єктом відносин у сфері використання ДРТ виступають особисті немайнові блага, а саме репродуктивне здоров'я. Договірні правовідносини у сфері використання з допоміжних репродуктивних технологій виникають на підставі положень цивільного законодавства; регламентовані нормами цивільного права; учасники зазначених правовідносин є юридично самостійними; захист порушених прав здійснюється тільки судом.

Пропонуємо виокремити наступні ознаки правовідносин з використання допоміжних репродуктивних технологій: суб’єкти цих правовідносин $є$ рівними між собою і не перебувають у прямому адміністративному підпорядкуванні один одного; суб'єктний склад зазначених правовідносин (фізичні та юридичні особи); вольовий характер цих 


\section{Цивільне, підприємницьке, господарське та трудове право}

правовідносин; підставою виникнення, припинення та зміни цих правовідносин $є$ договір; захист прав і законних інтересів здійснюється у суді.

Одним із визначальних структурних елементів правовідносин 3 використання допоміжних репродуктивних технологій $\mathrm{E}$ ïх суб'єкти. Суб'єкти правовідносин - це особи, організації або спільноти, які на підставі правових норм можуть бути учасниками правовідносин - носіями юридичних прав та обов'язків [5; с. 9].

У правовідносинах з використання допоміжних репродуктивних технологій беруть участь як фізичні, так і юридичні особи.

До фізичних осіб ми відносимо: потенційних батьків, тобто осіб, які проходять репродуктивне лікування з метою народження дитини; донорів репродуктивних клітин або ембріонів; сурогатних матерів, тобто жінок, які народжують дитину для потенційних батьків [6; с. 193].

До юридичних осіб суб'єктів правовідносин 3 ДРТ належать: заклади охорони здоров'я, у яких проводиться ДРТ; юридичні компанії; агентства з репродуктивних технологій, які надають консультативні та організаційні послуги учасникам ДРТ; страхові компанії.

Таким чином приходимо до висновку, що суб'єктами зазначених правовідносин у сфері репродукції людини є фізичні та юридичні особи. Суб'єкти зазначених правовідносин є юридично рівними, а також наділені взаємними правами та обов'язками. Для прикладу, правам потенційних батьків кореспондують обов’язки сурогатної матері, а правам сурогатної матері кореспондують обов’язки потенційних батьків.

Досліджуючи суб'єктний склад правовідносин 3 використання допоміжних репродуктивних технологій, ми пропонуємо розподілити суб'єктів на основних і факультативних.

Основними суб'єктами відносин у сфері репродукції є суб'єкти, без участі яких зазначені правовідносини виникнути не можуть: потенційні батьки, сурогатна матір, донори ембріонів та репродуктивних клітин, заклади охорони здоров'я, де використовується
ДРТ. Пропонуємо наступні визначення зазначених суб'єктів:

- Потенційні батьки - це особи, що досягли повноліття, мають повний обсяг дієздатності, які звернулися з власної ініціативи або були направлені за медичними показами до закладів охорони здоров’ я, які використовують допоміжні репродуктивні технології для перевірки стану свого репродуктивного здоров'я з метою народження дитини за допомогою репродуктивних технологій.

- Сурогатна мати - це особа, що досягла повноліття, має повний обсяг дієздатності, психічно і фізично здорова жінка, що має власних здорових дітей і надає свою добровільну письмову згоду виносити, народити та передати потенційним батькам дитину на основі договору безоплатно чи за плату. Жінки не повинні мати медичних протипоказань до сурогатного материнства.

- Донор статевих клітин (гамет) - це доросла людина, з повним обсягом дієздатності, фізично та психічно здорова, яка передає свої гамети (ооцити чи сперму) за добровільною письмовою згодою іншій людині для лікування безпліддя.

- Донор ембріону - це особи, що досягли повноліття, мають повний обсяг дієздатності та у яких після проведення заходів з використання допоміжних репродуктивних технологій залишились невикористані кріоконсервовані ембріони у кріобанку, за добровільною письмовою згодою передають їх іншим особам для лікування безпліддя.

- Заклади охорони здоров'я- юридичні особи будь-якої організаційно-правової форми та форми власності або їх відокремлені підрозділи, основними завданнями яких $\epsilon$ проведення медичного обслуговування населення на основі відповідних дозволів та ліцензій.

Факультативні суб'єкти беруть участь у правовідносинах 3 ДРТ і надають окремі послуги основним суб'єктам. Факультативні суб'єкти стають учасниками правовідносини $з$ використання ДРТ, коли є потреба у їхніх послугах, i їх участь не є обов’язковою у зазначених правовідносинах. Відсутність таких суб'єктів не впливає на результат застосування ДРТ. 
До факультативних суб’єктів можна віднести: страхові компанії, юридичні компанії, агентства 3 допоміжних репродуктивних технологій.

Суб’єктів правовідносин з застосування ДРТ, окрім поділу на основних та факультативних, також можна класифікувати на:

1)суб'єктів, що надають медичні послуги - заклади охорони здоров'я, які застосовують ДРТ;

2)суб'єкти, що здійснюють юридичний супровід - юридичні компанії, адвокати;

3) суб'єкти, що надають консультативні, організаційні послуги- агентство 3 ДРТ;

4) суб'єкти учасники медичної програми ДРТ- сурогатна матір, потенційні батьки, донори репродуктивних ембріонів та клітин.

У законодавстві України не існує визначення поняття «мати», зі змісту Сімейного кодексу випливає, що підставою виникнення батьківських прав є вагітність. Ця позиція визначається теорією, яка виникла ще за часів римського права, де діяв принцип mater est quam gestatio demonstrate («мати визначається вагітністю») [7; с. 603].

У ст. 122 СК України вказується, що походження дитини від матері встановлюється на підставі документів, що підтверджують народження дитини матір'ю в медичній установі [8]. У ситуації, що розглядається, 3 одного боку, гени дитини збігаються 3 генами подружжя, а з іншого боку, весь біологічний матеріал, 3 якого формується організм дитини (поживні речовини, які протягом дев’яти місяців споживає організм), надає сурогатна мати.

Законодавець вважає, що факт виношування і народження дитини є більш соціально та емоційно значущим, ніж його генетичне походження. Більше того, «моральні страждання біологічних батьків дитини, які втратили можливість реалізувати свої батьківські права щодо дитини, визнаються менш соціально значущими, ніж страждання сурогатної матері» [9; с. 82].

У Конституції України зазначено, що права і свободи людини належать їй від народження [10]. Однак, якщо не було вироблено процедури державної реєстрації народження дитини, то її інтереси підлягають правовому захисту в не повній мірі.
Чи може дитина, державна реєстрація народження якої не була проведена, бути суб'єктом права? Таким чином, сьогодні у вітчизняному законодавстві склалося таке становище, при якому державній реєстрації народження, яка, по суті, має другорядний характер, надається значення правовстановлюючого факту. Це стало однією з причин того, що в юридичній літературі все частіше висловлюються пропозиції про те, що в законі необхідно визначити момент виникнення батьківських прав та обов'язків. Таким моментом, на думку M.Міччел (Nahman, Michal R. (2018)), слід вважати встановлення факту вагітності жінки [11]. На його думку, вже в період ембріонального розвитку дитина повинна бути наділена правом на турботу з боку батьків, на забезпечення інтересів дитини і їі всебічний розвиток. При цьому батьки повинні нести відповідальність за виховання і розвиток своїх дітей, навіть тих, що знаходяться в утробі матері.

Проте різні правові системи, різні рівні культурного розвитку, різні законодавчі підходи до вирішення принципового питання про законність штучного переривання вагітності (аборт) не дозволяють на міжнародному рівні визнати дитину суб'єктом прав ще до його народження.

Відзначимо, що в ст. 7 Конвенції ООН про права дитини сказано, що народження дитини має бути зареєстровано відразу ж після ії фактичного народження. Саме з моменту народження дитина має:

- право на ім'я;

- право на набуття громадянства,

- право знати своїх батьків, наскільки це можливо реалізувати,

- право на турботу батьків. [12]

Сучасне сімейне законодавство України на чільне місце в процесі визнання батьківства ставить його реєстрацію в органах реєстрації актів цивільного стану. Реєстрація батьківства - внесення відомостей про батька до актового запису про народження дитини. Реєстрація батьківства $є$ обов'язковою умовою для виникнення сімейних правовідносин між батьком і дитиною.

Таким чином, без реєстрації громадянина як батька народженої дитини його батьківські права не виникають, відповідно, ніх- 


\section{Цивільне, підприсмницьке, господарське та трудове право}

то (включаючи органи правосуддя) не має права змусити чоловіка виконувати батьківські обов'язки. Разом з тим, чинний порядок посвідчення походження дитини від батька дозволяє реєстрацію як батька дитини особи, яка фактично батьком не $є$.

В Україні дозволено анонімне донорство гамет. Проте, можливі конфлікти, суперечки та порядок ії вирішення поки законодавчо не врегульовані. Вважаємо, що дитина, народжена від неанонімного донора, має право отримати інформацію про свого біологічного батька. Це право має бути законодавчо закріплено. Вважаємо, що реалізувати це право дитина може після досягнення повноліття. Причому, необхідно закріпити, що реалізувати це право вона може незалежно від згоди матері. Вважаємо, що закріпити таку норму важливо для самоідентифікації і для реалізації права дитини знати своїх батьків (ст. 7 Конвенції ООН про права дитини) [12].

Звертаючись до питання припинення правовідносин з використання допоміжних репродуктивних технологій слід зазначити, що це питання багато в чому безпосередньо пов'язане 3 договором про використання допоміжних репродуктивних технологій якщо існує договір, то існують правовідносини, якщо ж немає договору, то і правовідносини припиняються.

На думку автора, правовідносини 3 використання допоміжних репродуктивних технологій припиняються в трьох випадках.

По-перше, правовідносини припиняються виконанням договору про використання допоміжних репродуктивних технологій. Відповідно до норми пункту 1 статті 598 ЦК України належне виконання припиняє зобов'язання [13].

Як уже не раз зазначалося, договір про використання допоміжних репродуктивних технологій укладають у цілях лікування безпліддя потенційних батьків шляхом народження в інтересах потенційних батьків дитини і встановлення в майбутньому дитячобатьківських відносин як сімейної цінності.

3 правової точки зору, дитячо-батьківські відносини виникають у момент, коли потенційні батьки набувають статусу законних батьків дитини. Відповідно до положень СК України права і обов'язки батьків і дітей грунтуються на походженні дітей, засвідченому у встановленому законом порядку. Встановленим законом порядком мається на увазі процедура запису батьків дитини в книзі реєстрації актів цивільного стану та видачі свідоцтва про народження дитини. Саме 3 цього моменту потенційні батьки визнаються законними батьками дитини і у них виникають дитячо-батьківські відносини.

Отже, $з$ цього моменту можна вважати, що досягнута мета договору про використання допоміжних репродуктивних технологій, а саме: встановлені дитячо-батьківські відносини між потенційними батьками і дитиною, які закріплюють сімейні цінності, до яких вони прагнули з одного боку, і завершена процедура лікування безпліддя потенційних батьків з іншого боку.

Звідси випливає висновок, що виконання договору припинено, а значить, і правовідносини також припинені.

По-друге, правовідносини у сфері використання допоміжних репродуктивних технологій можуть бути припинені фактом розірвання договору. У статті 653 ЦК України встановлено, що зобов'язання сторін припиняються у разі розірвання договору. Наприклад у сторін договору сурогатного материнства існуе право, за певних умов, розірвати договір сурогатного материнства. Отже, за відсутності договору відсутні і правовідносини. У такому випадку правовідносини сурогатного материнства припиняються в момент розірвання договору сурогатного материнства.

По-третє, правовідносини у сфері використання допоміжних репродуктивних технологій можуть бути припинені в разі неможливості їх виконання.

Відповідно до пункту 1 статті 607 ЦК України зобов'язання припиняється неможливістю виконання, якщо воно зумовлено обставиною, що настала після виникнення зобов'язання, за яку жодна із сторін не відповідає [13].

На жаль, репродукція, як і будь-яка медична послуга, не може гарантувати позитивний результат, у цьому випадку народження дитини. Можлива ситуація, коли 3 тих чи інших обставин вагітність закінчиться невдало. При такому розвитку подій кін- 
цева мета не може бути досягнута, дитина не народжується і не передається потенційним батькам, у яких, у свою чергу, не може виникнути дитячо-батьківських відносин. Так як вагітність сурогатної матері припиняється, не досягнувши необхідного результату, то можна говорити, що виконати договір сурогатного материнства неможливо. Отже, припиняється договір та правовідносини сурогатного материнства.

Аналогічна ситуація відбувається і в разі смерті сурогатної матері. Пункт 1 статті 607 ЦК України говорить, що зобов'язання припиняється смертю боржника, якщо виконання не може бути проведено без особистої участі боржника або зобов'язання іншим чином нерозривно пов'язано $з$ особистістю боржника.

Так як у правовідносинах сурогатного материнства особистість сурогатної матері має істотне значення, то іï смерть припиняє договір сурогатного материнства.

У разі ж смерті потенційних батьків, застосуємо пункт 2 статті 608 ЦК України, який встановлює, що зобов'язання припиняється із смертю кредитора, якщо виконання призначене особисто для кредитора або зобов'язання іншим чином нерозривно пов’язано з особою кредитора.

Так як сурогатне материнство реалізується тільки в інтересах потенційних батьків, то в разі їх смерті, правовідносини також припиняються.

\section{Висновки з цього дослідження і перспективи подальших досліджень у цьому напрямі}

Таким чином, на основі вищевикладених міркувань можна стверджувати, що:

1. Правовідносини у сфері використання допоміжних репродуктивних технологій виникають у момент укладення договору про використання допоміжних репродуктивних технологій $з$ метою лікування безпліддя потенційних батьків за допомогою народження в їх інтересах дитини сурогатною матір'ю для встановлення дитячо-батьківських відносин як сімейної цінності потенційних батьків.

2. Правовідносини у сфері використання допоміжних репродуктивних технологій припиняються: а. У момент виконання договору, а саме в момент запису потенційних батьків законними батьками дитини в книзі реєстрації актів цивільного стану, тобто в момент встановлення дитячо-батьківських відносин між дитиною і потенційними батьками.

b. У момент розірвання договору.

c. У разі неможливості виконання договору припиненням вагітності, смертю сурогатної матері або смертю потенційних батьків.

\section{Література}

1. Про затвердження Порядку застосування допоміжних репродуктивних технологій в Україні: Наказ Міністерства охорони здоров’'я від 09.09.2013 № 787 URL: https://zakon.rada.gov.ua/laws/show/z169713\#Техt (Дата звернення 18.04.2021 р.)

2. Whittaker A., Speier A. (2020) "Cycling overseas": care, commodification and stratification in cross-border reproductive travel // Medical Anthropology. 2020. Oct. 29(4). P. 363-383.

3. Greil AL, Slauson-Blevins KS, Lowry M, et al. (2019) Concerns about treatment for infertility in a probability-based sample of US women. Journal of Reproductive and Infant Psychology 38: 16-24.

4. Piersanti, V., Consalvo, F., Signore, F., Del Rio, A., \& Zaami, S. (2021). Surrogacy and "Procreative Tourism". What Does the Future Hold from the Ethical and Legal Perspectives?. Medicina (Kaunas, Lithuania), 57(1), 47. https:// doi.org/10.3390/medicina57010047

5. Johnson L, Regulation of assisted reproductive treatment (ART) in Aus-tralia \& current ethical issues// The Indian journal of medical research, 2014 Nov; 140(Suppl 1): S9-S12. https:/www.ncbi.nlm.nih.gov /pmc/articles/ PMC4345760/ Дата обращения 23.04.2018 г.

6. Odorico J.S, Kaufman D.S., Thomson J.A. Multilineage differentiation from human embryonic stem cell lines // Stem Cells. - 2001. Vol. 19, N 3, - P. 193-204.

7. Cromer, Risa. 2019. Making the ethnic embryo: Enacting race in US embryo adoption. Medical Anthropology: Cross Cultural Studies in Health and Illness 38 (7): 603619. https://doi.org/10.1080/01459740.2019.15 $\underline{91394 .}$

$$
\text { 8. Сімейний кодекс }
$$
України від 10 січня 2002 року 


\section{Цивільне, підприсмницьке, господарське та трудове право}

№ 2947-III URL: https://zakon.rada.gov.ua/ laws/show/2947-14\#Text (Дата звернення 18.04.2021 p.)

9. $\mathrm{Hu}$, Yuwei. 2018. After woman finds her baby via surrogate unhealthy, Chinese surrogacy agency says she can 'return it' for new one. Global Times, 22 January 2018. http:// www.globaltimes.cn/content/1086012.shtml. Accessed 26 January 2020.

10. Конституція України від 28 червня 1996 року URL: https://zakon. rada.gov.ua/laws/show $/ 254 \%$ D 0\%BA/96$\% \mathrm{D} 0 \% \mathrm{~B} 2 \% \mathrm{D} 1 \% 80 \# \mathrm{Text}$ (Дата звернення 18.04.2021 p.)

11. Nahman, Michal R. 2018 Migrant extractability: Centring the voices of egg providers in cross-border reproduction. Reproductive Biomedicine \& Society Online 7: 82-90. https:// doi.org/10.1016/j.rbms.2018.10.020.

12. United Nations (2020). "Chapter IV. Human Rights. 11) Convention on the Rights of the Child" in: United Nations Treaty Collection. Depositary. Status of Treaties. Archived 8 September 2020 at the Wayback Machine. Retrieved 8 September 2020. URL: https://en.wikipedia. org/wiki/Convention_on_the_Rights_of_the_ Child (Дата звернення 18.04.2021р.)

13. Цивільний кодекс України від 16 січня 2003р., Відомості Верховної Ради України. - 2003., No. 40-44., ст. 356. (Дата звернення 06.04.2021 р.)

14. Weis, C. Changing Fertility Landscapes: Exploring the Reproductive Routes and Choices of Fertility Patients from China for Assisted Reproduction in Russia. ABR 13, 7-22 (2021). https://doi.org/10.1007/s41649-020-00156-w

Davydiuk Khrystyna, postgraduate Private International Law Chair, Institute of international relations Taras Shevchenko National University of

Kyiv

STRUCTURE AND CONTENT OF LEGAL RELATIONS ARISING IN THE FIELD OF APPLICATION OF ASSISTED REPRODUCTIVE TECHNOLOGIES

The aim of the research paper is identification, analysis and generalisation of the structure and content of legal relations arising in the field of application of assisted reproductive technologies.

Model: The research methodology involved the following methods: comparative method, systematisation, and social survey of employees of medical organisations that provide services of assisted reproductive technologies, case law review.

Conclusions: As a result of the study, the author notes that the legal relationship in the use of assisted reproductive technologies arises at the time of the agreement on the use of assisted reproductive technologies to treat infertility of potential parents by giving birth by a surrogate mother to establish child-parent relationship as a family value of potential parents.

Research scope: the study was conducted using national and foreign experience of the legal regulation of public relations with the study of the case law of Ukraine and the member states of the Council of Europe.

Practical value of the research: The results of the research can be used both in the preparation of sectoral legislation and in the preparation of draft agreements on the use of assisted reproductive technologies.

Social implications of the research: The development of special legislation in the field of reproductive technologies will ensure the implementation of the principle of legal certainty in society, reduce conflicts between people involved in these relations, and may increase the number of children born in Ukraine.

Uniqueness: The paper emphasises the importance of legislative consolidation of the structure and content of legal relations arising in the field of assisted reproductive technologies, identifies a range of issues that can be regulated by the legislator, and can be identified and resolved by parties to the contract before their legislative enshrinement.

Key words: legal regulation, legal relations, principles, assisted reproductive technology (ART), medical technologies, in vitro fertilization (IVF), human embryo, bioethics. 